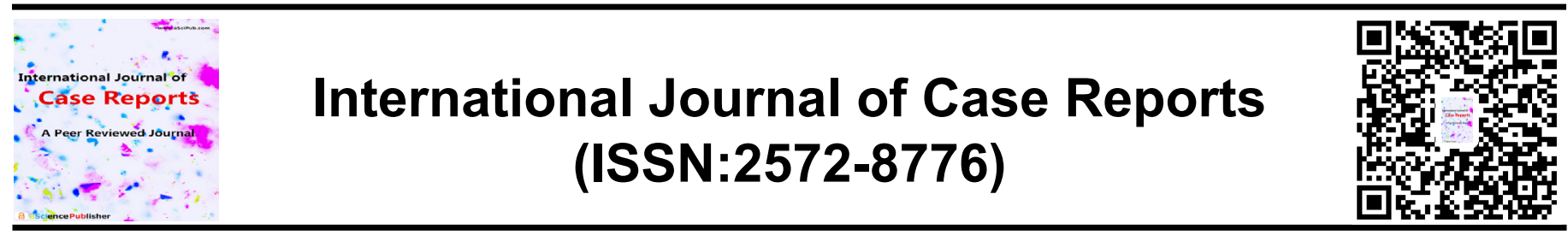

\title{
COVID-19 infection In Beta Thalassemia Major: Case series
}

\author{
Lina Okar ${ }^{1 *}$, Maya Aldeeb $^{1}$, Rita Ahmad ${ }^{1}$, Mohamed A. Yassin ${ }^{2}$ \\ ${ }^{1}$ Department of Medical Education, Hamad Medical Corporation, Doha, Qatar. \\ ${ }^{2}$ Department of Medical Oncology, Hematology Section, National Center for Cancer Care \& Re- \\ search, Hamad Medical Corporation, Doha, Qatar.
}

\section{ABSTRACT}

COVID-19 infection was first described in Wuhan, China after an increasing spread of atypical pneumonia of unknown pathogen. Unfortunately, this novel virus continues spreading causing a pandemic. Thalassemia considered one of the most common hemoglobinopathies. Beta thalassemia is the commonest type with a variety in clinical picture due to the deference in 30 homozygous. A lot of vulnerable categories were at high risk of getting infected with the coronavirus and more even its Fax complication. Despite the conflicting data and ongoing research on this topic, thalassemia patients were categorized among the high-risk population.

Here we present a case series describing the clinical progression of two splenectomised patients who has transfusion dependent beta thalassemia major.

Keywords: COVID-19; Beta Thalassemia Major; Haemoglobinopathies; Splenectomy; blood transfusion
*Correspondence to Author:

Dr. Lina Okar

Family Medicine Department Hamad Medical Corporation Al Rayan Street, Doha, PO Box 3050, Qatar.

Tel: 00974500190804

Fax Number: 0097444397857

How to cite this article:

Lina Okar, Maya Aldeeb, Rita Ahmad, Mohamed A. Yassin. COVID-19 infection In Thalassemia beta major: Case series. International Journal of Case Reports, 2020; 4:161.

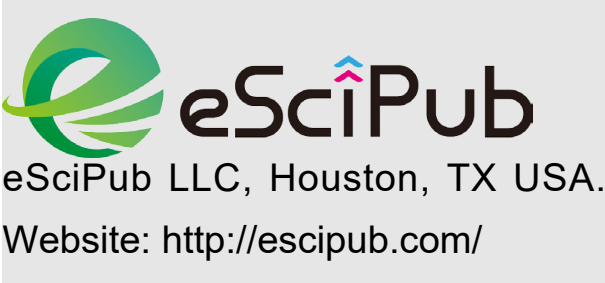




\section{Introduction}

Starting from Wuhan in China the novel Coronavirus was first discovered in December 2019 after the spread of atypical pneumonia without known pathology. On 11 February 2020, WHO named it as COVID-19 (coronavirus disease 2019) that spread rapidly causing a global pandemic. COVID-19 virus belongs to a group of severe acute respiratory coronaviruses (SARSCoV), thus it was named as SARS-CoV-2.

Similar to the SARS-CoV and Middle East respiratory syndrome coronavirus MERS-CoV, COVID-19 main presentation was lower respiratory tract syndrome that can even lead to SARS ${ }^{[1]}$. The clinical course of COVID-19 infection is variable amongst those who are infected. Asymptomatic infection was described as well as the progression to SARS. However, the presenting symptoms was categorized into typical symptoms such as fever, dry cough, myalgia, dyspnea and anorexia or atypical presentations like gastrointestinal symptoms or hyponatremia ${ }^{[2,3]}$. Haemoglobinopathies consider the most common recessive monogenic globally. Consisting of two large groups: The thalassemia syndromes and the hemoglobin defects. Thalassemia has many types, $\alpha, \beta$, and $\delta \beta$ thalassemia are significantly important clinically. Depending on the homozygotes Beta thalassemia may present as major or intermediate thalassemia. This wide variant result in a range of clinical pictures. Beta thalassemia major (BTM) patients are most likely to be diagnosed earlier and become blood transfusion dependent for their whole life whereas beta thalassemia intermedia (BTI) patients have milder disease course, thus diagnosed later life. Depending on this clinical course Thalassemia was categorized into transfusion dependent thalassemia (TDT) and non-transfusion dependent thalassemia (NTDT) ${ }^{[4,5]}$

COVID-19 pandemic was considered to cause a real challenge for haemoglobinopathies patients, their surroundings including families and medical staff as per the statement from Thalassemia international Federation (TIF) which published on the 13th of July 2020 considering patients with hemoglobinopathies at greater risk to get the infection. However, they also emphasized the lack of evidence regarding the clinical course of COVID-19 infections in this category of patients ${ }^{[6]}$. Here we present a description of two BTM cases infected with COVID-19 in Qatar.

\section{Case presentation}

During the pandemic of COVID-19 infection in Qatar, two cases of male and female with TDBTM presented to our hospital, after initial investigations they appeared to be COVID-19 positive. In fact, they had somehow smooth clinical course of infection. A detailed description of the cases is described in the following table:

Table 1.

\begin{tabular}{|c|c|c|}
\hline & Case 1 & Case 2 \\
\hline Age (years) & 31 & 30 \\
\hline Gender & Female & Male \\
\hline Nationality & Pakistani & Qatari \\
\hline Blood type & B negative & TD - BTM \\
\hline Co-morbidities & TD - BTM & Mositive \\
\hline Iron overload & Diabetes Mellitus type II & Moderate liver overload. \\
& Mild myocardial overload. & Yos mocardial overload. \\
\hline Splenectomy & Yes & Positive \\
\hline Source of infection & Sick contact & Asymptomatic \\
\hline $\begin{array}{c}\text { Nasopharyngeal swab } \\
\text { result }\end{array}$ & Positive & NA \\
\hline $\begin{array}{c}\text { Presenting symptoms } \\
\text { Duration of symptoms }\end{array}$ & Fever, Sore throat, dyspnea, fatigue, and \\
\hline
\end{tabular}

IJCR: https://escipub.com/international-journal-of-case-reports/ 
Lina Okar et al., IJCR, 2020; 4:161

\begin{tabular}{|c|c|c|}
\hline Hospital admission & Yes & Yes \\
\hline \multicolumn{3}{|c|}{ Investigations } \\
\hline Chest Xray: & $\begin{array}{l}\text { There are multiple subtle opacities in bilat- } \\
\text { eral mid and lower zones suggestive of in- } \\
\text { fective changes }\end{array}$ & Not done \\
\hline ECG & $\begin{array}{c}\text { QTc } \\
\text { No signs of ischemia }\end{array}$ & $\begin{array}{c}\text { QTc } \\
\text { No signs of ischemia }\end{array}$ \\
\hline \multicolumn{3}{|c|}{ Blood tests: } \\
\hline $\begin{array}{l}\text { Hemoglobin } \\
(13-17 \mathrm{gm} / \mathrm{dL})\end{array}$ & 9.1 & 7.8 \\
\hline $\begin{array}{c}\text { RBCs } \\
\left(4.5-5.5 \times 10^{6}\right)\end{array}$ & 4.2 & 2.8 \\
\hline $\begin{array}{c}\text { WBCs } \\
\left(4-10 \times 10^{3} / \mathrm{UL}\right)\end{array}$ & 15.93 & 7.1 \\
\hline $\begin{array}{c}\mathrm{PLT} \\
\left(150-400 \times 10^{3} / \mathrm{UL}\right)\end{array}$ & 535 & 845 \\
\hline $\begin{array}{l}\text { Lymphocytes count } \\
\qquad\left(1-3 \times 10^{3} / \mathrm{UL}\right)\end{array}$ & 27.9 & 47.8 \\
\hline $\begin{array}{c}\text { Ferritin } \\
(8-252 \mathrm{mcg} / \mathrm{L}) \\
\end{array}$ & 11,574 & 431 \\
\hline $\begin{array}{c}\text { CRP } \\
(0-5 \text { Umg/L) }\end{array}$ & 13 & 4.2 \\
\hline $\begin{array}{c}\text { D-dimer } \\
(0.00-0.4 \mathrm{mcg} / \mathrm{L})\end{array}$ & 0.60 & NA \\
\hline $\begin{array}{c}\text { LDH } \\
(135-214 \mathrm{U} / \mathrm{L})\end{array}$ & 451 & 41 \\
\hline $\begin{array}{l}\text { Renal function tests } \\
\quad(\text { Urea / Cr) } \\
(2.1-8.8 \mathrm{mmol} / \mathrm{L}) \\
(44-80 \mathrm{Umol} / \mathrm{L})\end{array}$ & $4.40 / 15$ & $5.9 / 79$ \\
\hline $\begin{array}{l}\text { ALT / AST } \\
(0-33 \mathrm{U} / \mathrm{L}) \\
(0-32 \mathrm{U} / \mathrm{L}) \\
\end{array}$ & $180 / 247$ & $33 / 41$ \\
\hline $\begin{array}{c}\text { Albumin } \\
(35-50 \mathrm{gm} / \mathrm{L})\end{array}$ & 33.5 & 45 \\
\hline G6PD & Normal & Normal \\
\hline $\begin{array}{l}\text { Length of hospital stay } \\
\text { (days) }\end{array}$ & 12 & 1 \\
\hline Clinical course & $\begin{array}{c}\text { Stable } \\
\text { No oxygen supplementation was needed }\end{array}$ & $\begin{array}{l}\text { Stable } \\
\text { No oxygen supplementation } \\
\text { was needed }\end{array}$ \\
\hline $\begin{array}{l}\text { COVID-19 specific } \\
\text { treatment }\end{array}$ & $\begin{array}{c}\text { Yes: } \\
\text { Azithromycin for } 500 \mathrm{mg} \mathrm{BID} \text { for } 7 \text { days. } \\
\text { Dexamatasone } 6 \mathrm{mg} \text { daily for } 7 \text { days. } \\
\text { Enoxaparin } 40 \mathrm{mg} \mathrm{Sc} \text { daily. }\end{array}$ & No \\
\hline Blood transfusion & Yes & Yes \\
\hline Iron chelation therapy & $\begin{array}{c}\text { Yes } \\
\text { Deferasirox } 1080 \mathrm{mg} \text { daily. }\end{array}$ & $\begin{array}{c}\text { Yes } \\
\text { Deferasirox } 720 \mathrm{mg} \text { daily. }\end{array}$ \\
\hline Outcome: recovery & improved & asymptomatic course \\
\hline Isolation & Yes & Yes \\
\hline $\begin{array}{l}\text { COVID-19 repeated } \\
\text { result. }\end{array}$ & $\begin{array}{c}\text { Negative } \\
\text { Interval between the positive and negative } \\
\text { results was } 3 \text { weeks. }\end{array}$ & $\begin{array}{l}\text { As per our guidelines if the pa- } \\
\text { tient is asymptomatic then iso- } \\
\text { lation without repeating the } \\
\text { swab. }\end{array}$ \\
\hline
\end{tabular}




\section{Discussion}

The initial source of SARS-CoV-2 is still unknown despite all previously suggested primary sources like sea food or even the bat. Multiple mechanism of transmission was prescribed, most importantly via droplet, close contact as well aerosol if continuous exposure and close environment are present and rarely it was suggested that due to the gastrointestinal symptoms as vomiting and diarrhea, this may be another route of getting infected. The clinical presentation of COVID-19 infection is variant ranging from asymptomatic cases to critically ill with severe acute respiratory syndrome (SARS). Symptoms were categorized as typical and atypical. Typical symptoms include fever, dry cough, myalgia, dyspnea and less commonly sore throat, runny nose, and headache, whereas atypical symptoms are gastrointestinal in nature like vomiting, diarrhea, and nausea. Hyponatremia, loss of smell or test are also reported. ${ }^{[3,7,8]}$

Thalassemia and sickle cell disease are the most common monogenic disorders in human among inherited hemoglobin disorder and haemoglobinopathies. Beta thalassemia is a common type of thalassemia syndrome occurs due to inherited defect in hemoglobin synthesis that leads to persistent hemolysis and earlier death of Red blood cells (RBCs) in their cycle of life, thus compensatory expansion in the boon marrow as well chronic anemic status ${ }^{[9-11]}$.

The classification of thalassemia depends on its genetic background and clinical picture, Beta thalassemia major (BTM), beta thalassemia intermedia (BTI) and Beta thalassemia minor (BTM) are the main categories. From clinical aspect Beta thalassemia can be classified into transfusion dependent thalassemia (TDT) and non-transfusion dependent thalassemia (NTDT). Usually BTM is diagnosed earlier in life than BTM due to the severe anemia and the need for blood transfusion to survive. Thalassemia patients need a well-defined plan and close follow up due to the multisystemic involvement and the lifelong therapy. The most noticeable side effects from recurrent blood transfusion are infection transmission, antibody formation and most importantly iron overload with cardiovascular and liver diseases being the leading cause of morbidity and mortality ${ }^{[11-15]}$.

Thalassemia can lead also to osteoporosis, hypogonadotropic hypogonadism, affect growth, spermatogenesis and adrenocortical function [1619].

Thus, Iron chelation therapy (ICT) consider a cornerstone in the management plan as it alleviates the morbidities associated this complication [20,21].

Despite the paucity in literature regarding COVID-19 infection in hemoglobinopathies patients, this virus is still causing a real challenge in haemoglobinopathies patients and their surrounding including family and medical staff due to the multiple hospital visits. They are as well at risk of developing complication if there are any co-morbidities like viral illness. Mostly because of the multiple organ involvement which occurs in thalassemia patients due to iron overload and chronic anemia status that affect the heart, lungs, liver, and endocrine glands. Thus, those patients were added to other vulnerable population at risk of COVID-19 infection and complications [6,21].

Also, Previous studies demonstrated that beta thalassemia patients tend to have may changes in their immune system like higher levels of $\mathrm{LL}$ $1 \alpha$, TNF- $\alpha$ and IL-1 $\beta$, IL-6, IL-8, C-reactive protein, neopterin, reduced C3 level and complement activity. Therefore, those patients are more prone to respiratory compromise than normal population. Contrary, the available data hypothesized that beta-chain changes in thalassemia patients might have a protective role against covid-19 infection ${ }^{[22-24] .}$

While splenectomy, a common intervention in thalassemia patients, was thought to play a role in pulmonary hypertension, its role in the progression of COVID-19 infections in Thalassemia patients still vague. However, upon the current literature it seems that splenectomy does not increase the risk of COVID-19 infection or even worsen it is course. A will recognized reasons that increase the risk of infections are iron overload, reduced immunity, multiple blood 
transfusions and in older patients splenectomy and adrenal hypofunction might have a role $[21,25]$
Here we present a brief conclusion from the literature regarding the prognosis of COVID-19 infection in thalassemia major patients. ${ }^{[24,26-29]}$

Table 2.

\begin{tabular}{|c|c|c|c|c|c|}
\hline Study name & Type of study & $\begin{array}{l}\text { Patient } \\
\text { number }\end{array}$ & $\begin{array}{l}\text { Mean } \\
\text { age }\end{array}$ & Splenectomy & $\begin{array}{l}\text { Conclusion regarding the } \\
\text { outcome }\end{array}$ \\
\hline $\begin{array}{l}\text { Prevalence and mortality in } \\
\text { b-thalassemia due to out- } \\
\text { break of novel coronavirus } \\
\text { disease (COVID-19): the na- } \\
\text { tionwide Iranian experience }\end{array}$ & $\begin{array}{l}\text { Multicentric, } \\
\text { retrospective, } \\
\text { cross sectional } \\
\text { study }\end{array}$ & 15 & $\begin{array}{l}36 \pm 12 \\
\text { years }\end{array}$ & $\begin{array}{l}12 \text { patients out } \\
\text { of } 15\end{array}$ & $\begin{array}{c}11 \text { recovered } \\
4 \text { died }\end{array}$ \\
\hline $\begin{array}{l}\text { SARS-CoV-2 infection in } \\
\text { beta thalassemia: Preliminary } \\
\text { data from the Italian experi- } \\
\text { ence10 }\end{array}$ & $\begin{array}{l}\text { Single center } \\
\text { cohort study }\end{array}$ & 11 & $\begin{array}{c}44 \pm 11 \\
\text { years }\end{array}$ & $\begin{array}{l}8 \text { patients out } \\
\text { of } 11\end{array}$ & $\begin{array}{l}10 \text { recovered } \\
1 \text { died }\end{array}$ \\
\hline $\begin{array}{l}\text { Impact of SARS CoV-2 in He- } \\
\text { moglobinopathies with Im- } \\
\text { mune Disfunction and Epide- } \\
\text { miology. A Protective Mecha- } \\
\text { nism from Beta Chain Hemo- } \\
\text { globin Defects? }\end{array}$ & $\begin{array}{l}\text { Cross sec- } \\
\text { tional }\end{array}$ & $\begin{array}{l}105 \text { TDT } \\
\text { screened } \\
1 \text { female } \\
\text { positive }\end{array}$ & 59 years & yes & $\begin{array}{c}\text { one old female tested } \\
\text { positive and she was } \\
\text { asymptomatic, repeated } \\
\text { test was negative after } 14 \\
\text { days }\end{array}$ \\
\hline $\begin{array}{l}\text { COVID-19 in a Patient with } \\
\beta \text {-Thalassemia Major and Se- } \\
\text { vere Pulmonary Arterial Hy- } \\
\text { pertension }\end{array}$ & Case report & 1 & $\begin{array}{c}57 \\
\text { years old }\end{array}$ & yes & $\begin{array}{c}\text { Patient had } \\
\text { severe pulmonary artery } \\
\text { hypertension } \\
\text { was admitted for } 10 \text { days, } \\
\text { then recovered }\end{array}$ \\
\hline $\begin{array}{c}\text { Preliminary Data on COVID- } \\
19 \text { in Patients with Hemoglo- } \\
\text { binopathies: A Multicenter } \\
\text { ICET-A Study }\end{array}$ & $\begin{array}{l}\text { Multicenter } \\
\text { ICET-A Study }\end{array}$ & $\begin{array}{l}4962 \\
\text { TDT } \\
7 \text { of them } \\
\text { tested } \\
\text { positive }\end{array}$ & $\begin{array}{c}35.7 \pm 11 \\
.3 \\
\text { years }\end{array}$ & 4 & $\begin{array}{c}5 \text { patients were females } \\
3 \text { patients had DM } \\
6 \text { patients had mild to } \\
\text { moderate symptoms and } \\
\text { recovered } \\
\text { One patient had severe } \\
\text { COVID pneumonia and } \\
\text { died }\end{array}$ \\
\hline
\end{tabular}

\section{Conclusion}

Due to the recent global pandemic caused by Coronavirus and the impact in the society, haemoglobinopathies patients are at risk to be infected as their disease may push them into visiting the hospital more than other patients. As well the lack of data that describe the clinical progression of COVID-19 infections among those patients makes it hard to predict the outcome for them till now. Multiple studies are conducting to reach a clear conclusion. Till then, preventive measurement and close monitoring for hemoglobinopathies patients is the cornerstone to prevent them from being infected at the first place. A good outcome is describer before yet due to the lack in reporting cases of COVID-19 in haemoglobinopathies patients we believe it is worthy to present this case series of two beta thalassemia patients who recovered successfully from COVID-19 infections without any complications even though both were splenectomized and one patient has diabetes as a co-morbidity.

\section{Acknowledgment}

We would like to acknowledge the Family medicine residency program at Hematology section as well as Hamad Medical Corporation for their support.

\section{Statement of Ethics}

Consent was obtained from the patients. Case approved by HMC Medical Research center

\section{Declaration of interest}

The authors report no conflicts of interest.

\section{Authors contribution:}

All authors contributed equally in writing the manuscript. 


\section{References}

[1] Wang $Y$, Wang $Y$, Chen $Y$, Qin Q. Unique epidemiological and clinical features of the emerging 2019 novel coronavirus pneumonia (COVID-19) implicate special control measures. J Med Virol 2020;92:568-76. https://doi.org/10.1002/jmv.25748.

[2] Pascarella G, Strumia A, Piliego C, Bruno F, Del Buono R, Costa F, et al. COVID-19 diagnosis and management: a comprehensive review. J Intern Med 2020;288:192-206. https://doi.org/10.1111/joim.13091.

[3] Ata F, Almasri H, Sajid J, Yousaf Z. COVID-19 presenting with diarrhoea and hyponatraemia. BMJ Case Rep 2020;13:235456. https://doi.org/10.1136/bcr-2020-235456.

[4] De Sanctis V, Kattamis C, Canatan D, Soliman AT, Elsedfy H, Karimi M, Daar S, Wali Y, Yassin M, Soliman N, Sobti P. $\beta$-thalassemia distribution in the old world: an ancient disease seen from a historical standpoint. Mediterranean journal of hematology and infectious diseases. 2017;9(1).

[5] Kanbour I, Chandra P, Soliman A, De Sanctis V, Nashwan A, Abusamaan S, et al. Severe liver iron concentrations (LIC) in 24 patients with $\beta$ thalassemia major: Correlations with serum ferritin, liver enzymes and endocrine complications. Mediterr J Hematol Infect Dis 2018;10:20 18062.

https://doi.org/10.4084/MJHID.2018.062.

[6] Okar, L, Ali, M, Parengal, J, Yassin, MA. COVID-19 and thalassemia beta major in splenectomized patient: Clinical case progression and literature review. Clin Case Rep. 2020; 00: 1- 5. https://doi.org/10.1002/ccr3.3345

[7] Soliman AT, Prabhakaran Nair A, AI Masalamani MS, et al. Prevalence, clinical manifestations, and biochemical data of type 2 diabetes mellitus versus nondiabetic symptomatic patients with COVID-19: A comparative study. Acta Biomed. 2020;91(3):e2020010. Published 2020 Sep 7. doi:10.23750/abm.v91i3.10214

[8] Mullol J, Alobid I, Mariño-Sánchez F, IzquierdoDomínguez A, Marin C, Klimek L, et al. The Loss of Smell and Taste in the COVID-19 Outbreak: a Tale of Many Countries. Curr Allergy Asthma Rep 2020;20. https://doi.org/10.1007/s11882-020-00961-1.

[9] Nashwan AJ, Yassin MA, Babu GDJ, Nair SLK, Libo-On IL, Hijazi HA, et al. Quality of life among adolescents aged 14 to 18 years with beta-thalassemia major (TM) in Qatar. Acta Biomed 2018;89:16-26.

https://doi.org/10.23750/abm.v89i2-S.7083.
[10] Yassin MA, Soliman AT, de Sanctis V, Abdula MAJ, Riaz LM, Ghori FF, et al. Statural growth and prevalence of endocrinopathies in relation to liver iron content (LIC) in adult patients with beta thalassemia major (BTM) and sickle cell disease (SCD). Acta Biomed 2018;89:33-40. https://doi.org/10.23750/abm.v89i2-S.7085.

[11] Yassin M, Soliman A, De Sanctis V, Nashwan A, Abusamaan S, Moustafa A, Kohla S, Soliman D. Liver iron content (LIC) in adults with sickle cell disease (SCD): correlation with serum ferritin and liver enzymes concentrations in trasfusion dependent (TD-SCD) and non-transfusion dependent (NT-SCD) patients. Mediterranean Journal of Hematology and Infectious Diseases. 2017;9(1).

[12] Soliman AT, Yassin M, Yafei F Al, Al-Naimi L, Almarri N, Sabt A, et al. Longitudinal study on liver functions in patients with thalassemia major before and after deferasirox (DFX) therapy. Mediterr J Hematol Infect Dis 2014;6:2014025. https://doi.org/10.4084/MJHID.2014.025.

[13] Soliman A, Al Yafei F, Al-Naimi L, Almarri N, Sabt $A$, Yassin $M$, et al. Longitudinal study on thyroid function in patients with thalassemia major: High incidence of central hypothyroidism by 18 years. Indian J Endocrinol Metab 2013;17: 1090. https://doi.org/10.4103/2230-8210.122635.

[14] De VS, Soliman A, Candini G, Campisi S, Anastasi $S$, lassin M. High prevalence of central hypothyroidism in adult patients with $\beta$-thalassemia major. Georgian medical news. 2013 $\operatorname{Sep}(222): 88-94$

[15] Soliman A, Yasin M, El-Awwa A, De Sanctis V. Detection of glycemic abnormalities in adolescents with beta thalassemia using continuous glucose monitoring and oral glucose tolerance in adolescents and young adults with $\beta$-thalassemia major: Pilot study. Indian J Endocrinol Metab 2013;17:490. https://doi.org/10.4103/2230-8210.111647.

[16] Yassin MA, Soliman AT, De Sanctis V, Abdelrahman MO, Aziz Bedair EM, Abdelgawad M. Effects of the anti-receptor activator of nuclear factor kappa $\mathrm{B}$ ligand denusomab on beta thalassemia major-induced osteoporosis. Indian J Endocrinol Metab 2014;18:546-51. https://doi.org/10.4103/2230-8210.137516.

[17] Soliman A, Yasin M, El-Awwa A, Osman M, De Sanctis V. Acute effects of blood transfusion on pituitary gonadal axis and sperm parameters in adolescents and young men with thalassemia major: A pilot study. Fertil Steril 2012;98:63843.

https://doi.org/10.1016/j.fertnstert.2012.05.047. 
[18] Soliman AT, Yassin MA, De Sanctis V. Final adult height and endocrine complications in young adults with $\beta$-thalassemia major (TM) who received oral iron chelation (OIC) in comparison with those who did not use OIC. Acta Biomed 2018;89:27-32. https://doi.org/10.23750/abm.v89i2-S.7084.

[19] Soliman A, Yassin M, Majuid NMSA, Sabt A, Abdulrahman $M$, De Sanctis V. Cortisol response to low dose versus standard dose (back-to-back) adrenocorticotrophic stimulation tests in children and young adults with thalassemia major. Indian J Endocrinol Metab 2013;17: 1046. https://doi.org/10.4103/2230-8210.122620.

[20] Yassin MA, Soliman AT, De Sanctis V, Hussein RM, Al-Okka R, Kassem N, Ghasoub R, Basha A, Nashwan AJ, Adel AM. Jadenu $\AA^{\circledR}$ substituting Exjade $\AA$ in iron overloaded $\beta$-thalassemia major (BTM) patients: a preliminary report of the effects on the tolerability, serum ferritin level, liver iron concentration and biochemical profiles. Mediterranean journal of hematology and infectious diseases. 2018;10(1).

[21] De Sanctis V, Canatan D, Lluis J, Corrons V, Karimi M, Daar S, et al. A Comprehensive Update of ICET-A Network on COVID-19 in Thalassemias: What We Know and Where We Stand. Maria Concetta Galati 2020;10:0-000. https://doi.org/10.23750/abm.v91i3.10063.

[22] Patpan N, Banjerdpongchai R, Tantiworawit A, Poofery J, Komonrit P, Fanhchaksai K, et al. The Effect of Transfusion-Dependent Thalassemia Patient's Serum on Peripheral Blood Mononuclear Cell Viability. J Cell Death 2019;12:11 7906601882353.

https://doi.org/10.1177/1179066018823534.

[23] Lansiaux E, PébajPP, Picard JL, Son -Forget J. COVID-19: beta-thalassemia subjects immunised? Med Hypotheses 2020;142:109827. https://doi.org/10.1016/j.mehy.2020.109827.

[24] Torti L, Maffei L, Sorrentino F, De Fabritiis $P$, Miceli R, Abruzzese E. Impact of SARS CoV-2 in hemoglobinopathies: a protective mechanism being from Beta chain Hemoglobin defects? Mediterr J Hematol Infect Dis 2020;12:e2020 052. https://doi.org/10.4084/mjhid.2020.052.

[25] Pinto VM, Derchi GE, Bacigalupo L, Pontali E, Forni GL. COVID-19 in a Patient with $\beta$-Thalassemia Major and Severe Pulmonary Arterial Hypertension. Hemoglobin 2020:1-4. https://doi.org/10.1080/03630269.2020.177908 2.

[26] Karimi M, Haghpanah S, Azarkeivan A, Zahedi Z, Zarei T, Akhavan Tavakoli M, et al. Prevalence and Mortality due to Outbreak of Novel
Coronavirus Disease (COVID-19) in $\beta$-Thalassemias: The Nationwide Iranian Experience. $\mathrm{Br}$ J Haematol 2020. https://doi.org/10.1111/bjh.16911.

[27] Motta I, De Amicis MM, Pinto VM, Balocco M, Longo $F$, Bonetti $F$, et al. SARS-CoV-2 infection in beta thalassemia: preliminary data from the Italian experience. Am J Hematol 2020:198-9. https://doi.org/10.1002/ajh.25840.

[28] Pinto VM, Derchi GE, Bacigalupo L, Pontali E, Forni GL. COVID-19 in a Patient with $\beta$-Thalassemia Major and Severe Pulmonary Arterial Hypertension. Hemoglobin 2020;0:1-4. https://doi.org/10.1080/03630269.2020.177908 2.

[29] De Sanctis V, Canatan D, Corrons JL, Karimi M, Daar S, Kattamis C, Soliman AT, Wali Y, Alkindi S, Huseynov V, Nasibova A. Preliminary data on COVID-19 in patients with hemoglobinopathies: a multicentre icet-a study. Mediterranean Journal of Hematology and Infectious Diseases. 2020;12(1). 